ENTREPRENEURSHIP AND SUSTAINABILITY ISSUES

ISSN 2345-0282 (online) http://jssidoi.org/jesi/

2020 Volume 8 Number 2 (December)

http://doi.org/10.9770/jesi.2020.8.2(71)
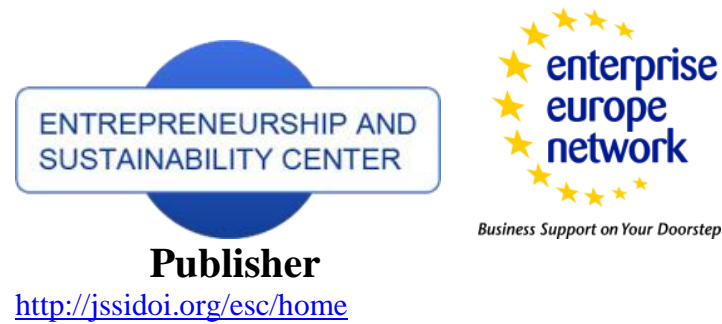

CASPA

Scopus

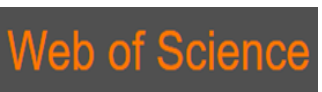

http://jssidoi.org/esc/home

\title{
LIMITS OF STATE REGULATORY POWER IN INVESTMENT LAW AND UNDER NATIONAL LEGISLATION: SEARCH FOR COMMON DENOMINATOR
}

\author{
Solveiga Paleviciene ${ }^{1}$, Simona Drukteiniene ${ }^{2}$ \\ ${ }^{1,2}$ Mykolas Romeris University Law School, Ateities Str. 20, 08303 Vilnius, Lithuania \\ E-mails: ${ }^{1}$ solveiga@mruni.eu; ${ }^{2}$ simona@mruni.eu
}

Received 18 August 2020; accepted 10 October 2020; published 30 December 2020

\begin{abstract}
Recent years have seen a considerable increase in the amount of investment cases against both developing and developed countries. In many of those cases, investors attempted to challenge a number of sensitive and political decisions of States. This trend provoked a discussion of whether it is legitimate to limit a State's regulatory power, even if the measures taken impact on investors' rights and legal expectations. This paper highlights the importance of finding a reasonable and just balance in the protection of a State's sovereign power to regulate and an investor's legitimate expectations and rights against the unreasonable, unexpected, and discriminatory decisions of States. It is argued that the possibility and necessity of finding a common dominator in national legislation and International investment law exists. The aim of this article is to identify the main rules applicable to the limits of a State's regulatory changes impacting on investors' rights and legitimate expectations in investment law and under national legislation. Further, the article analyses whether it is possible to find a just and reasonable balance between the investors' legal expectations and the State's right to regulate by comparing the main differences and similarities between national and investment law and by answering the question of whether it would be possible to harmonise State liability rules on the issue, at least at the conceptual level.
\end{abstract}

Keywords: investment law; state liability; state regulatory power; expropriation; fair and equitable treatment; legitimate expectations

Reference to this paper should be made as follows: Drukteiniene S. Paleviciene S. 2020. Limits of State regulatory power in investment law and under national legislation: search for common denominator. Entrepreneurship and Sustainability Issues, 8(2), 1197-1210. http://doi.org/10.9770/jesi.2020.8.2(71)

JEL Classifications: K20, L31

Additional disciplines: law

\section{Introduction}

Recent years have seen a considerable increase in the amount of investment cases against both developing and developed countries. Many cases have been brought against European Union (hereafter - EU) countries in the energy sector for the abolition or considerable decrease of incentives for the generation of electricity from renewable resources, principally wind and solar. Most of the claims have been brought against Spain, where 40 investment 


\section{ENTREPRENEURSHIP AND SUSTAINABILITY ISSUES}

ISSN 2345-0282 (online) http://jssidoi.org/jesi/

2020 Volume 8 Number 2 (December)

http://doi.org/10.9770/jesi.2020.8.2(71)

Make your research more visible, join the Twitter account of ENTREPRENEURSHIP AND SUSTAINABILITY ISSUES: @Entrepr69728810

treaty arbitrations have been filed, along with seven cases against the Czech Republic and nine cases against Italy (Kaiser, 2019). In those cases, investors targeted the State's regulatory decisions made for public purposes. Therefore, EU countries together with EU institutions started to argue that the possibility for investors to challenge sensitive political decisions regarding important reforms for public purpose before private arbitral tribunals illegitimately limits the regulatory powers of the State.

Eventually, together with a number of other arguments, the concerns expressed by several States triggered international investment dispute (hereafter - ISDS) reform. For example, the EU proposal on the Investment Court System for Transatlantic Trade and Investment Partnership (hereafter - TTIP), and other EU trade and investment negotiations, expressly confirms governments' rights to set the regulatory provisions, and suggest the clarification of the concepts of indirect expropriation and fair and equitable treatment, introducing safeguards that would enable governments to keep control over the interpretation of investment provisions (European Commission, 2015). Further, currently most of the new generation of bilateral investment treaties (hereafter - BITs) and free trade agreements (hereafter - FET) directly provide that, except in rare circumstances, non-discriminatory regulatory actions by a party that are designed and applied to protect legitimate public welfare objectives, such as public health, safety, and the environment, do not constitute indirect expropriations (OECD, 2004).

At first glance, even after the implementation of considerable reform in investment law, the scope of the right to challenge regulatory measures seems to be better protected in the case of foreign investors than domestic investors. Traditionally under investment law it is accepted that investment protection may provide the opportunity to challenge State regulatory measures without deep contemplation on differences of disputable State actions (legislative or otherwise). On the contrary, under national laws the possibility to sue legislator has always been mission almost impossible, because in order to sue a State national investors must generally follow national tort law (or constitutional and property law) rules designed for State liability, or prove general conditions for tort liability and overcome numerous additional substantial and procedural hurdles. Therefore, the possibility to challenge legislative actions was or still is prevented in a number of States.

The question is whether it is truly just and reasonable to limit such a possibility under national legislation, and/or whether it is legitimate to give more protection to foreign investors to challenge State regulatory measures at all, when such rights for national investors are still very limited.

From a purely legal point of view, if we accept that the purpose of investment law is to provide more incentives for foreign investments, then logically there is nothing wrong with giving more legal protection to foreign investors. However, politically, investment law is valid only until a consensus that it is necessary to protect investors exists among States. Therefore, it is clear that in order for investment law to exist it is necessary to create such a system that could meet the expectations of all its stakeholders and find the right balance between the legitimate expectations of investors and the State's power to regulate in both national and international investment law.

The aim of this article is to identify the main rules applicable to the limits of regulatory changes having impacts on investors' rights and their legitimate expectations, both in investment law and under national legislation. Further, the objective is to discuss whether it is possible to find a just and reasonable balance between the investors' legal expectations and the State's right to regulate, by comparing the main differences and similarities between national law and investment law and by answering the question of whether it would be possible and necessary to harmonise State liability rules on the issue - at least at the conceptual level. 


\section{ENTREPRENEURSHIP AND SUSTAINABILITY ISSUES}

ISSN 2345-0282 (online) http://jssidoi.org/jesi/

2020 Volume 8 Number 2 (December)

http://doi.org/10.9770/jesi.2020.8.2(71)

Make your research more visible, join the Twitter account of ENTREPRENEURSHIP AND SUSTAINABILITY ISSUES: @Entrepr69728810

The article first examines the position of investment arbitral tribunals towards the change of State regulatory measures, identifying the extent to which the investor is legitimately entitled to expect that national law is not going to change after they have performed their investment. In the second part, the focus is on national legislation on the issue of identifying procedural and substantial regulatory challenges that national investors face in seeking just compensation for losses incurred due to State actions. Finally, the authors perform a comparative analysis of the rules of investment law and national law on the issue, and discuss the possibility of finding a common denominator for State liability in the case of regulatory changes having an impact on investors' rights.

\section{The position of investment arbitral tribunals under fair and equitable treatment and expropriation rules provided in international investment treaties}

Investors' rights and expectations in investment law against State regulatory measures are usually covered by the protection of the legitimate expectations of investors as a key component of FET, a concept that runs throughout most international investment treaties (hereafter - IITs). Most IITs also prohibit direct and indirect expropriation, therefore, in case of complete distortion of foreign investments, investors may also claim compensation under the rules of expropriation. In general, investment law does not deny the State's sovereign regulatory power nor prevent the State from acting in the public interest, even though it could impair foreign investments. Therefore, international arbitral tribunals and legal doctrine recognize a State's power to regulate, accepting that the State has a sovereign right to regulate or take other measures affecting foreign investors' property interests or legitimate expectations without finding compensable expropriation in certain circumstances (Gjuzi, 2018; Butler \& Subedi, 2017).

However, according to the standard of FET, even without specific representation or commitment (including a stabilization clause), a minimum level of consistency and predictability of the legal framework in the host State should be observed.

Usually it is required that such measures must pursue a legitimate purpose, be aimed at the general welfare, be nondiscriminatory, and fall within the ambit of the State's general regulatory or administrative powers (Dolzer \& Schreuer, 2008, p. 91). The State should follow certain substantive and procedural principles, including fairness, non-discrimination, proportionality, transparency, and due process in their governance. For example, in the case of Ioan Micula and others v. Romania (2013) the tribunal stated that "the state may always change its legislation, being aware and thus taking into consideration that: (i) an investor's legitimate expectations must be protected; (ii) the state's conduct must be substantively proper (e.g., not arbitrary or discriminatory); and (iii) the state's conduct must be procedurally proper (e.g., in compliance with due process and fair administration). If a change in legislation fails to meet these requirements, while the legislation may be validly amended as a matter of domestic law, the state may incur international liability" (paras. 520, 529).

However, at the same time the investor is also supposed to accept all the realities of the actual investment environment in the host country when undertaking the investment, including its level of development and its particular circumstances (Gjuzi, 2018). Therefore, the investor has no absolute right to expect that there will never be any regulatory changes. For example, in the case of Parkerings-Compagniet AS v. Republic of Lithuania (2007) the Tribunal stated that: "As a matter of fact, any businessman or investor knows that laws will evolve over time. What is prohibited however is for a State to act unfairly, unreasonably or inequitably in the exercise of its legislative power".

In the case of Continental Casualty v. Argentine Republic (2008), the Arbitral tribunal stated: "it would be unconscionable for a country to promise not to change its legislation as time and needs change, or even more to tie 


\section{ENTREPRENEURSHIP AND SUSTAINABILITY ISSUES}

ISSN 2345-0282 (online) http://jssidoi.org/jesi/

2020 Volume 8 Number 2 (December)

http://doi.org/10.9770/jesi.2020.8.2(71)

Make your research more visible, join the Twitter account of ENTREPRENEURSHIP AND SUSTAINABILITY ISSUES: @Entrepr69728810

its hands by such a kind of stipulation in case of crisis of any type or origin arose. Such an implication as to stability in the BIT's Preamble would be contrary to an effective interpretation of the Treaty; reliance on such an implication by a foreign investor would be misplaced and, indeed, unreasonable" (para. 258).

Newly negotiated investment treaties establish more sophisticated provisions on indirect expropriation and FET, reaffirming the State's right to regulate. They also directly exclude certain types of State regulation - even those that harm investments - from the definition of indirect expropriation or more detailed provisions, providing a list of factors intended to help tribunals with their interpretation when assessing claims of indirect expropriation.

International legal doctrine and investment arbitral tribunals have taken different approaches to State regulatory measures. For example, under expropriation rules it is possible to identify the "sole effects" approach; the doctrine of the proportionality and the legitimate objectives of the State as an exception from expropriation (Fortier \& Drymer, 2004, p. 309).

Under the sole effect doctrine, it is only the damage suffered by the investor that counts when deciding whether or not a State measure constitutes an indirect expropriation. This theory is criticized as its strict application may have consequences for the host State's policy space, and is therefore considered to be insufficient to establish the existence of indirect expropriation when "legitimate" public regulations are at issue (Nikièma, 2012).

The doctrine of the proportionality of the measure is defined as that of finding a balance between two contradictory interests, in this case the public and the private (Nikièma, 2012). However, it is criticized as a relatively unfamiliar concept in international investment law that cannot be directly transferred from forums of human rights dispute resolution.

The third approach is based on the idea that certain legitimate host State measures with specific characteristics cannot be considered as indirect expropriations, even when they are seriously and irreversibly detrimental to an investment. The main criticism of this theory is the difficulty of implementation and determination of the legitimate police power measures that are worth taking into account, along with justifying non-compensation of the damage suffered by investors (Nikièma, 2012).

Under the rules of the protection of legitimate expectations provided by FET, legal doctrine has identified the following approaches: a) the first approach, based solely on the concept of ensuring a stable legal and business framework; b) the second approach - more restrictive, requiring a specific representation to have been made by the State, including contractual obligations set out in a contract or the existence of a specific commitment between the host State and the investor, or mentioned in a legal measure, before amendment, with the purpose of attracting investment; c) the third approach (presented in the paper by the United Nations Conference on Trade and Development, 2012), which makes the claim of legitimate expectations subject to a number of qualifying requirements.

Under the first approach, a fair and equitable standard of treatment entails an element of stability of the regulatory framework and establishes a good governance obligation of the State: its administrative, governmental, legislative, and judicial system (Tecmed, S.A. v. United Mexican States, 2003). Under this approach, stability of the legal and business framework is an essential element of fair and equitable treatment, and "there is certainly an obligation not to alter the legal and business environment in which the investment has been made" (Occidental Petroleum Corporation and Occidental Exploration and Production Company v. The Republic of Ecuador, 2005, paras. 183, 191). 


\section{ENTREPRENEURSHIP AND SUSTAINABILITY ISSUES}

ISSN 2345-0282 (online) http://jssidoi.org/jesi/

2020 Volume 8 Number 2 (December)

http://doi.org/10.9770/jesi.2020.8.2(71)

Make your research more visible, join the Twitter account of ENTREPRENEURSHIP AND SUSTAINABILITY ISSUES: @Entrepr69728810

If the legal framework governing the investment changes in a way that was not anticipated or foreseen by the investor at the time of making the investment, then the investor should be compensated for the cost of complying with those changes. This means that if a new law is adopted, or an existing law is revoked or interpreted or applied in a new way, those changes can trigger State liability (Tecmed, S.A. v. United Mexican States, 2003, para. 154; Suez, Sociedad General de Aguas de Barcelona S.A., and InterAgua v. The Argentine Republic, 2010, para. 207; Total SA v. The Argentine Republic, 2010, para. 122).

The second approach accepts that, as a matter of principle, the State's right to regulate cannot be considered frozen or restricted as a result of the existence of investment treaties. In the opinion of Prof. Z. Douglas, "[t]he Tecmed 'standard' is actually not a standard at all; it is rather a description of perfect public regulation in a perfect world, to which all States should aspire but very few (if any) will ever attain" (2014, p. 28). Therefore, no investor may reasonably expect that the circumstances prevailing at the time the investment is made will remain totally unchanged. "It is now established in international law that States are not liable to pay compensation to a foreign investor when, in the normal exercise of their regulatory powers, they adopt in a non-discriminatory manner bona fide regulations that are aimed at the general welfare" (Saluka Investments v. The Czech Republic, 2006, paras. 255, 305, 351). It is each State's undeniable right and privilege to exercise its sovereign legislative power. A State has the right to enact, modify, or cancel a law at its own discretion. Due diligence is required from the investor, who "must anticipate that the circumstances could change, and thus structure its investment in order to adapt it to the potential changes of legal environment" (Parkerings-Compagniet AS v. Republic of Lithuania, 2007, para. 333). Save for the existence of an agreement, in the form of a stabilisation clause or otherwise, there is nothing objectionable about an amendment brought to the regulatory framework existing at the time an investor made its investment (para. 332).

Under the third approach, the crucial question becomes that of balance between stability and legitimate expectations on the one hand, and the host State's right to amend the regulatory framework on the other (Potestà, 2013). This approach requires proof of a number of interconnected elements to find a breach of legitimate expectations, and has recently been followed in many arbitration cases.

According to this theory, generally, legitimate expectations may arise only from a State's specific representations or commitments to the investor, on which the latter has relied. Investment treaties do not generally act to freeze the law unless those changes are contrary to a specific commitment made by the State (AES Summit Generation Limited and AES-Tisza Erömü Kft v. The Republic of Hungary, 2010, para. 9.3.34.). “...[A]bsent explicit undertakings directly extended to investors and guaranteeing that States will not change their laws or regulations, investment treaties do not eliminate States' right to modify their regulatory regimes to meet evolving circumstances and public needs...(Eiser Infrastructure Limited and Energía Solar Luxembourg S.à r.l. v. Kingdom of Spain, 2017, para. 362).

In the absence of a stabilisation clause or a similar commitment changes in the regulatory framework would be considered as breaches of the duty to grant full protection and fair and equitable treatment only in case of a drastic or discriminatory change in the essential features of the transaction (Toto Costruzioni Generali S.p.A. v. The Republic of Lebanon, 2012, para. 244).

The investor must be aware of the general regulatory environment in the country, and expectations must be reasonable and founded on the political, socioeconomic, cultural, and historical conditions prevailing in the State. Therefore, investors' expectations must be balanced against the legitimate regulatory activities of the host country. "[T]he legitimate expectations of foreign investors cannot be that the State will never modify the legal framework, 


\section{ENTREPRENEURSHIP AND SUSTAINABILITY ISSUES}

ISSN 2345-0282 (online) http://jssidoi.org/jesi/

2020 Volume 8 Number 2 (December)

http://doi.org/10.9770/jesi.2020.8.2(71)

Make your research more visible, join the Twitter account of ENTREPRENEURSHIP AND SUSTAINABILITY ISSUES: @Entrepr69728810

especially in times of crisis, but certainly investors must be protected from unreasonable modifications of that legal framework" (Impregilo S.p.A. v. Argentine Republic, 2011, para. 291). The legitimate expectations of investors can nonetheless be frustrated by modifications of the existing regulatory framework provided that, in enacting such modifications, the State acted unreasonably, disproportionately, or contrary to the public interest.

The tribunal in the case of Masdar v. Spain concluded that the investors had legitimate expectations that Spain would not make radical and fundamental changes to the legislation. It agreed that investors could not expect no changes to the legislation but were protected from radical and unexpected changes that would transform the legal and business systems (Masdar Solar Masdar Solar \& Wind v. Kingdom of Spain, 2018).

As to the proportionality, the changes would not be proportionate if they were capricious, unnecessary, or amounted to the sudden and unpredictable elimination of the essential characteristics of the existing regulation (Blusun S.A., Jean-Pierre Lecorcier and Michael Stein v. Italian Republic, 2016). Under the arbitral tribunal in the case of Blusun v. Italy, "in the absence of a specific commitment, the State has no obligation to grant subsidies such as feed-in tariffs, or to maintain them unchanged once granted. But if they are lawfully granted, and if it becomes necessary to modify them, this should be done in a manner which is not disproportionate to the aim of the legislative amendment, and should have due regard to the reasonable reliance interests of recipients who may have committed substantial resources on the basis of the earlier regime" (para. 319(5)).

Recognizing the inherent right of States to regulate, and thus rejecting any suggestion of an absolute right to regulatory stability, the Tribunal in the case of Eiser v. Spain concluded that the FET clause of the Energy Charter Treaty (hereafter - ECT) protected against "fundamental" changes in a manner that failed to take account of the circumstances of existing investments made in reliance on the prior regime and that led to "unprecedented", "totally different" regulatory regimes (Eiser Infrastructure Limited and Energía Solar Luxembourg S.à r.l. v. Kingdom of Spain, 2017). The Tribunal held that "taking into account the context, object and aim of the ECT, the Tribunal concludes that the obligation to provide fair and equitable treatment established by Article 10(1) necessarily implies an obligation to provide fundamental stability in the essential characteristics of the legal regime on which investors relied in making long-term investments. This does not mean that regulatory regimes cannot evolve. Clearly they can.... [but] they may not be so radically changed that they deny investors who made investments on the basis of such regimes of the value of their investment" (para. 352).

To summarize, it is obvious that confronting the sovereign right of the State to regulate whilst maintaining respect for the legitimate expectations of the investor raises many questions. The most important thing is to find a balance and harmony between these two concepts. Until now, tribunals were the main actors in determining and establishing such a balance. Currently, a trend of including more precise rules into the new generation of FTAs has arisen. However, the answer to the question of defining the correct balance between a State's regulatory power and an investor's legitimate expectations is still very subtle, and mostly depends on the precise evaluation of all of the circumstances in an individual case.

\section{National law of foreign countries: procedural and material hurdles}

The principle of separation of powers in national laws of many European countries excludes the State from delictual liability for enactments of primary legislation. Only in some countries liability in respect of legislation is recognized - Belgium, Greece, Poland, Portugal (Oliphant, 2016). However, even in these countries the investor seeking compensation will face important obstacles. First, in tort law compensation is payable if unlawfulness and (or) fault (wrongfulness) can be established. Ordinary standards of these prerequisites of liability are applied. Wide range of 


\section{ENTREPRENEURSHIP AND SUSTAINABILITY ISSUES}

ISSN 2345-0282 (online) http://jssidoi.org/jesi/

2020 Volume 8 Number 2 (December)

http://doi.org/10.9770/jesi.2020.8.2(71)

Make your research more visible, join the Twitter account of ENTREPRENEURSHIP AND SUSTAINABILITY ISSUES: @Entrepr69728810

discretion vested in legislative power might make proving of fault (wrongfulness) very difficult (SelelionytėDrukteiniene, 2008). Second, liability for losses suffered because of legislative act intended for public good is not easily accepted due to the policy considerations. Third, for understandable reasons connected with the doctrine of the separation of powers, it is understood that declaration of legislative act as unconstitutional is the necessary precondition for liability of the State for legislative wrongs.

In this regard liability for lawful conduct, i.e. obligation of the State to compensate for damage caused independently of unlawfulness and fault, might prove useful. Some European countries recognize the regime of liability for lawful conduct - the obligation to compensate for damage rests on the theories of egalité devant les charges publiques (equality in the distribution of public burdens) and Sonderopfertheorie (special sacrifice theory; Oliphant, 2016). The first theory originates in France and is understood that if losses result harm from measures taken in the general public interest but is suffered by limited group of persons and constitutes a disproportionate disadvantage for them (abnormal and special damage), such damage shall be compensated by the State. This theory, possibly with some modifications, is also accepted in Belgium, the Netherlands, Switzerland (Selelionytė-Drukteinienè, 2008; Oliphant, 2016). The second theory is vested in German law. According to this theory, "liability arises from expropriationlike intervention (enteignungsgleicher eingriff). The claim is based on the infringement of a property right, resulting in specific sacrifice (sonderopfer) for the general public benefit that others do not have to bear. In this context, property includes the right to an established and ongoing nosiness and encompasses the business's current assets but not its uncertain future profits" (Oliphant, 2016). This theory is also accepted in Poland and Portugal (Oliphant, 2016). However, application of these theories is very limited - abnormal and special damage is required under the theory equality in the distribution of public burdens. According to the German sacrifice theory, only certain types of property might be compensated, not to mention the fact that a successful claim is contingent upon the claimant having no other source of redress and exhausting all other legal options for avoiding the loss (Oliphant, 2016).

\subsection{National position of Lithuanian legislation and court practice on the State power to regulate}

Lithuanian acts - Article 23(3) of the Constitution, Articles 4.67, 4.93(4), 4.100-4.102 of the Civil Code of the Republic of Lithuania (hereinafter - the CC), chapter VIII of the Law on Land of the Republic of Lithuania, etc. provide for the detailed regulation of compensation for the expropriation of property. However, property is understood in a narrow, traditional sense: as an "objective" piece of property. Thus, the law of expropriation proves to be of no avail to investors seeking compensation for losses suffered due to changes of regulation.

On the other hand, there is no general clause in Lithuanian law following from Principle II of the Recommendation No. R (84) 15 of the Committee of Ministers to Member States Relating to Public Liability adopted by the Committee of Ministers of the Council of Europe on 18 September 1984 at the 375th meeting of the Ministers' Deputies (Council of Europe, 1984), whereby compensation should be ensured based on the principle of equality before public burdens, i.e. if it would be manifestly unjust to allow the injured person alone to bear the damage. Article 6.246(3) of the CC indicates that "[d]amage caused by lawful acts must be compensated only in cases expressly specified by laws". Thus, without explicit obligation to compensate for damage caused by lawful act, such compensation is not possible.

In these circumstances, the most feasible option available to the investor is to rely on the special rules of State liability set out in the CC. Article 6.271(1) of the CC indicates: "Damage resulting from unlawful acts of state authority institutions must be compensated by the state from the state budget, irrespective of the fault of a particular public servant or other employee of the state authority institutions. Damage resulting from unlawful actions of 


\section{ENTREPRENEURSHIP AND SUSTAINABILITY ISSUES}

ISSN 2345-0282 (online) http://jssidoi.org/jesi/

2020 Volume 8 Number 2 (December)

http://doi.org/10.9770/jesi.2020.8.2(71)

Make your research more visible, join the Twitter account of ENTREPRENEURSHIP AND SUSTAINABILITY ISSUES: @Entrepr69728810

municipal authority institutions must be compensated by the municipality from its own budget, irrespective of its employee's fault". Article 6.272 of the CC governs State liability for damage caused by the unlawful actions of State judiciary and law-enforcement institutions, and therefore is not relevant in this article.

Investors seeking compensation will meet certain obstacles. First of all, the unlawfulness of the State must be established. Article 6.271(4) of the CC sets out that unlawfulness in this delict shall be understood as an institution's or a servant's failure to act in the manner prescribed by laws. Though Article 6.271(1) of the CC is explained as providing for the strict liability of the State, by virtue of Article 6.271(4) organizational fault is in fact the condition of public liability. The requirement of organizational fault of the public institution is especially clear in cases involving acts with a certain margin of discretion - the courts require a serious transgression of discretion by the public institution (see e.g., AB ORLEN Lietuva v. the Republic of Lithuania represented by the Competition Council of the Republic of Lithuania, 2011). Moreover, the Lithuanian Supreme Administrative Court emphasizes that unlawfulness of public institution must always be proved by reference to a specific legislative provision which governs its functions; a mere reference to a breach of the general duty to act with due care is not sufficient to establish unlawfulness (see UAB Baltlanta v. the Republic of Lithuania represented by the Ministry of Agriculture of the Republic of Lithuania, 2015; Drukteinienè \& Šaltinytė, 2016).

Additionally, in certain areas special acts expressly indicate that the fault is the necessary precondition of public liability. For example, Article 45(1) of the Law on the Bank of Lithuania requires, since December 2015, the intent or gross negligence of the Central Bank or of its servants in case of damage resulting from the unlawful supervision of the financial market. Moreover, the burden of proof rests on the victim while, by virtue of Article 6.248(1) of the $\mathrm{CC}$, in regular cases of liability the fault of the defendant is presumed.

Secondly, the investor shall prove which institution or institutions are responsible for compensation. Lithuania adopted a victim-oriented model whereby the State (or municipality) itself is liable for the damage caused by the exercise of public authority. Thus, the liability rests on the State (municipality), not on its institutions or servants, and the defendant in the case is respectively the State or (and) municipality. However, item 3.23 of Decision No. 1054 of 29 September 2014 "On Appointment of the Representative of the State and the Government before Courts" adopted by the Government of Republic of Lithuania indicates the institutions who act as the representatives of the State in the case. So, in fact the plaintiff is obliged to demonstrate the unlawful actions (omission) of the particular public institution participating in the case as the representative of the defendant. The same is true with respect to cases where the damage has been caused by the municipal authority institutions.

Thirdly, compensation for damage caused by legislative wrongs is a topic still surrounded by much controversy. Since the enactment of the new CC in 2000, Article 6.271 was explained as applicable to the acts (omissions) carried out exercising executive power (Mikelènas, 2003). Later on, scholars proved that Article 6.271 could be applied when the cause of damage is an unlawful legislative act (Selelionytė-Drukteiniené, 2008; Mizaras, 2007). However, despite numerous attempts the courts have not explicitly accepted liability for legislative wrongs, save for in very narrow instances. Liability has only been accepted for breaches of basic human rights enshrined in the Convention for the Protection of Human Rights and Fundamental Freedoms (see e.g., AS v. the Republic of Lithuania represented by the Government of the Republic of Lithuania, 2010) and breaches of European Union law (see e.g., UV v. Republic of Lithuania, represented by the Ministry of Economy, 2017; LB et al. v. Republic of Lithuania, represented by the Ministry of the Economy, 2017; EP v. Republic of Lithuania, 2017). One of the most important obstacles can be found in regulation: Article 18(2) of the Law on Administrative Proceedings expressly states that administrative courts have no competence to rule on the activity of the Seimas. The authors believe that cases for the compensation of damage resulting from unlawful legislative acts shall fall under the competence of the general 


\section{ENTREPRENEURSHIP AND SUSTAINABILITY ISSUES}

ISSN 2345-0282 (online) http://jssidoi.org/jesi/

2020 Volume 8 Number 2 (December)

http://doi.org/10.9770/jesi.2020.8.2(71)

Make your research more visible, join the Twitter account of ENTREPRENEURSHIP AND SUSTAINABILITY ISSUES: @Entrepr69728810

courts. However, in practice these cases are directed to the administrative courts by the Special Board of Judges formed for Solving the Difficult Questions of the Delimitation of Competence Between the Administrative and the General Competence Courts.

Fourthly, due to the doctrine of the separation of powers, the declaration of a legislative act as unconstitutional is a necessary precondition for the liability of the State for legislative wrongs. For example, in a case initiated by a producer of solar energy who argued that he suffered damage in the form of lost income due to changes in the legislation, the Lithuanian Supreme Administrative Court stated that the question of whether the law is compatible with the Constitution does not fall under jurisdiction of administrative courts (UAB Sunrita v. Republic of Lithuania, 2015). The potential liability of the State is also narrowed by the rule established in the practice of the Constitutional Court that the rulings of the Constitutional Court are valid prospectively, according to Article 107(1) of the Constitution (which provides that a law (or part thereof) may not be applied from the day of official promulgation of the decision of the Constitutional Court that the act in question is in conflict with the Constitution of the Republic of Lithuania) and Article 72 of the Law on the Constitutional Court (which is the mirror image of Article 107(1) of the Constitution).

On 25 October 2011, the Constitutional Court adopted the ruling "On the Consequences of Recognition of a Legal Act as Being in Conflict with the Constitution" (see also the Rulings of the Constitutional Court of 13 May 2003, 30 Dec. 2003 and 22 Dec. 2010). The Constitutional Court explained in the ruling that as long as the Constitutional Court has not declared an act as unconstitutional, it is presumed that the law does not contradict the Constitution and that legal consequences of such acts are lawful. Article 72(4) of the Law on the Constitutional Court provides that decisions based on legal acts which have been declared unconstitutional should not be implemented, if they have not been implemented before a relevant ruling of the Constitutional Court has entered into force. The interpretation of this provision by the Constitutional Court is that Article 72 of the Law on the Constitutional Court does not provide for the exceptions from the principle of prospective validity of the rulings of the Constitutional Court. Parliament has the right to adopt legal regulation eliminating the negative effects of the act which has been applied and later declared unconstitutional. However, the Constitutional Court also noted that Article 72(4) of the Law on the Constitutional Court governs only situations where the act that has been declared unconstitutional has not been executed by the time the ruling of the Constitutional Court comes into force. Whether the act has been executed by the time the ruling of the Constitutional Court has come into force or not shall be decided by the court trying the case in question.

According to the Constitutional Court, Article 67(1) of the Law on the Constitutional Court consolidates one of the exceptions to the prospective power of Constitutional Court rulings. The norm indicates that if there are grounds to believe that a law or other legal act which should be applied in a particular case is in conflict with the Constitution, the court (judge) shall suspend the consideration of the case and apply to the Constitutional Court with a petition to decide whether the law or other legal act in question is in compliance with the Constitution. According to the motivation of the Constitutional Court, the ruling of the Constitutional Court on the unconstitutionality of the act shall have effect in that particular case. Obviously, such an interpretation of Article 107(1) of the Constitution and Article 72 of the Law on the Constitutional Court became an instrument to a great extent limiting the liability of the Lithuanian State for the acts adopted by legislative power.

It is worth mentioning that Justice E. Šileikis of the Constitutional Court made a concurring opinion concerning the Ruling of the Constitutional Court of 25 Oct. 2011. The justice agreed with the opinion of the Constitutional Court that Article 72 of the Law on the Constitutional Court does not contradict the Constitution. However, according to the justice, several important legal questions have been left unanswered in the Ruling of the Constitutional Court. 


\section{ENTREPRENEURSHIP AND SUSTAINABILITY ISSUES}

ISSN 2345-0282 (online) http://jssidoi.org/jesi/

2020 Volume 8 Number 2 (December)

http://doi.org/10.9770/jesi.2020.8.2(71)

Make your research more visible, join the Twitter account of ENTREPRENEURSHIP AND SUSTAINABILITY ISSUES: @Entrepr69728810

According to the justice, no distinction shall be made between the two groups of persons, where the first group has started litigation and the court trying their case has addressed the Constitutional Court with the question of constitutionality of an act, and the second has not started litigation before the Ruling of the Constitutional Court declaring the act as unconstitutional.

\section{Investment law and national legislation: seeking a common denominator}

If we compare the rules of national State lability legislation and the practice of national courts with the general protective standards established in IIT and investment arbitration practice, in reality the level of investment protection available to foreign investors can often exceed that which is available to domestic investors. For example, foreign investors usually have the ability to sue the State government without any differentiation between it and the actions of the State, whilst domestic investors will most likely have to pursue any dispute in the national courts and meet a number of subjective and objective, procedural and substantial hurdles in seeking State liability or just compensation for losses suffered due to regulatory changes. Therefore, access to investment arbitration is naturally considered to be a significant advantage for investors in such cases.

Whether such a situation and more favorable outcomes are fair or not is more a political than legal question. From the legal point of view, under IITs there is only a requirement of no less protection than that which is afforded to nationals. States cannot discriminate against foreign investors, and they must be treated no worse than domestic investors. Therefore, there is nothing wrong with States giving additional protection to foreign investors compared to domestic investors.

The legal question is whether these differences can be reasonably explained and justified, and/or whether we can somehow find a common denominator acceptable for national and investment laws in seeking more balance between the protection of investors' rights and respect for States' regulatory power.

If some years ago it would be difficult to compare what the reality was de facto by comparing similar situations, today we can find and in general compare a number of cases where claims have been brought before both national courts and investment tribunals. As an example, we can analyze the very famous Vattenfall case (Vattenfall $A B$ and others v. Federal Republic of Germany, ICSID Case No. ARB/12/12).

This dispute relates to the sudden decision of the German Government following the Fukushima disaster to close down all nuclear power stations without any compensation. In this case the Swedish company Vattenfall, together with others, claimed $€ 4.7$ billion as compensation for losses allegedly suffered due to Germany's decision to shut down all nuclear energy production.

The companies' claim was not so much that the decision itself to stop the production of nuclear energy in Germany caused their losses, but rather the unexpected political changes were responsible in this regard.

This case reached not only the investment arbitral tribunal but also the German Constitutional Court (CGG). The main question at issue was the following: must Germany compensate Vattenfall because the investments (property) of Vattenfall were unjustifiably expropriated (BVerfG, Urteil des Ersten Senats, 6 December 2016)?

Some authors argued that the conclusions of the GCC can to a large extent be applied in analogy to arbitration proceedings, because the arbitral tribunal in the same case also had to balance the protection of investments against the protection of public goods and regulatory policy space (Lavranos, 2016; Zielinski, 2017). In a decision of 6 December 2016, the GCC dismissed Vattenfall's expropriation claim, but held that Germany had violated their legitimate expectations. The GCC in this case decided that, despite the broad regulatory freedom of the State, the State must act within certain boundaries. The Court held that the amendment to the Law at issue constituted a breach 


\section{ENTREPRENEURSHIP AND SUSTAINABILITY ISSUES}

ISSN 2345-0282 (online) http://jssidoi.org/jesi/

2020 Volume 8 Number 2 (December)

http://doi.org/10.9770/jesi.2020.8.2(71)

Make your research more visible, join the Twitter account of ENTREPRENEURSHIP AND SUSTAINABILITY ISSUES: @Entrepr69728810

of Vertrauensschutz (Article 14(1) of the German Constitutional Law) - the domestic German equivalent of the protection of legitimate expectations - insofar as it did not provide for any transition periods or compensation for investments in nuclear power plants which declined in value following the 2011 reduction of the production volumes that had been allocated in 2010 (BVerfG, Urteil des Ersten Senats, 6 December 2016, para. 369).

Based on the principle of proportionality, the GCC found that the lack of any compensation for the complete reversal of its policy on nuclear power constituted a violation of the property rights of Vattenfall. The GCC confirmed that expropriation for public purposes is acceptable as long as it is accompanied by adequate compensation.

The GCC stated that Article 14(1) of the German Constitutional Law, under specific circumstances, protects legitimate expectations of the stability of the legal framework as the basis of investments. It does not guarantee the fulfillment of all investment expectations, and does not generally provide protection against changes in the economic legal framework and resulting changes in the market position of an investor. It does, however, provide for compensation in cases in which the State directly prevents or substantially limits the use of investments undertaken in justified reliance on a specific legal framework (Zielinski, 2017). Nevertheless, the State has broad powers in determining how to compensate, and is not obliged to spare investors from suffering any burden at all related to the changes (BVerfG, Urteil des Ersten Senats, 6 December 2016, paras. 371, 372, 382).

As the analysis in the first part of this Article showed, many investment arbitral tribunals approached this matter in the same way: when States create legitimate expectations, which in turn have resulted in investments, the investor can expect that the State acts in a reasonable and foreseeable manner. Therefore, in general, a common denominator in both national and investment law may be found.

\section{Conclusions}

The analysis of national legislation and investment law showed that there is no one, undisputable threshold/formula applicable in all types of situations towards the limits of State regulatory power having impact on investors' rights and legal expectations neither in national law nor investment law.

Both the systems of national law and investment law are cautious, recognizing each State's undeniable right and privilege to exercise its sovereign legislative power. A State has the right to enact, modify, or cancel a law at its own discretion.

The balancing test for application of liability is usually applicable, and consists of a number of legal factors that should be taken into consideration alongside the precise evaluation of all factual circumstances of a situation.

Overall, in both national and investment law not much difference in the legal issues raised can be found, therefore there is the possibility of finding a common dominator based on the idea that when States create legitimate expectations which in turn have resulted in investments, investors should be safeguarded and fairly compensated at least for the discriminatory, unreasonable, and unforeseeable behavior of States. 


\section{ENTREPRENEURSHIP AND SUSTAINABILITY ISSUES}

ISSN 2345-0282 (online) http://jssidoi.org/jesi/

2020 Volume 8 Number 2 (December)

http://doi.org/10.9770/jesi.2020.8.2(71)

Make your research more visible, join the Twitter account of ENTREPRENEURSHIP AND SUSTAINABILITY ISSUES: @Entrepr69728810

\section{References}

AB ORLEN Lietuva v. The Republic of Lithuania represented by the Competition Council of the Republic of Lithuania, Lithuanian Supreme Administrative Court 14 July 2011, Case No. A502-3034/2011.

AES Summit Generation Limited and AES-Tisza Erömü Kft v. The Republic of Hungary, ICSID Case No. ARB/07/22, Award, 23 Sep. 2010.

AS v. the Republic of Lithuania represented by the Government of the Republic of Lithuania, Lithuanian Supreme Administrative Court 29 Nov. 2010, Case No. A858-1452/2010.

Blusun S.A., Jean-Pierre Lecorcier and Michael Stein v. Italian Republic, ICSID Case No. ARB/14/3, Award, 27 Dec. 2016.

BVerfG, Urteil des Ersten Senats 6 Decmeber 2016 - 1 BvR 2821/11. BVerfGE 143, 246-396. Retrieved from http://www.bverfg.de/e/rs20161206_1bvr282111en.html

Butler, N., \& Subedi, S. (2017). The future of international investment regulation: Towards a World Investment Organisation? Netherlands International Law Review, 64(1), 43-72. https://doi.org/10.1007/s40802-017-0082-5

Continental Casualty v. Argentine Republic, ICSID Case No. ARB/03/9, Award, 5 Sep. 2008.

Council of Europe. (1984). Recommendation No. R (84) 15 of the Committee of Ministers to Member States Relating to Public Liability adopted by the Committee of Ministers of the Council of Europe on 18 September 1984 at the 375th meeting of the Ministers' Deputies. Retrieved from https://rm.coe.int/16804e3398

Drukteinienè, S., \& Šaltinyte, L. (2016). XVII. Lithuania. European Tort Law Yearbook, 5(1), 349-380. https://doi.org/10.1515/tortlaw2016-0119

Dolzer, R., \& Schreuer, C. (2008). Principles of international investment law. Oxford: Oxford University Press.

Douglas, Z. (2014). Nothing if not critical for investment treaty arbitration: Occidental, Eureko and Methanex. Arbitration International, 22(1), 27-52. https://doi.org/10.1093/arbitration/22.1.27

Eiser Infrastructure Limited and Energía Solar Luxembourg S.à r.l. v. Kingdom of Spain, ICSID Case No. ARB/13/36, Award, 4 May 2017.

EP v. Republic of Lithuania, Lithuanian Supreme Administrative Court 28 Nov. 2017, Case No. eA-697-662/2017.

European Commission. (2015, September 16). Commission proposes new Investment Court System for TTIP and other EU trade and investment negotiations [Press release]. Retrieved from http://europa.eu/rapid/press-release_IP-15-5651_lt.htm

Fortier, Y., \& Drymer, S. (2004). Indirect expropriation in the law of international investment: I know it when i see it, or caveat investor. ICSID Review: Foreign Investment Law Journal, 19(2), 293-327. https://doi.org/10.1093/icsidreview/19.2.293

Gjuzi, J. (2018). Stabilization clauses in international investment law: A sustainable development approach. New York: Springer. https://doi.org/10.1007/978-3-319-97232-9

Impregilo S.p.A. v. Argentine Republic, ICSID Case No. ARB/07/17 21, Award, 21 June, 2011.

Ioan Micula, Viorel Micula, S.C. European Food S.A, S.C. Starmill S.R.L. and S.C. Multipack S.R.L. v. Romania [I], ICSID Case No. ARB/05/20, Award, 11 Dec. 2013.

Kaiser, G. E. (2019). Arbitrations involving renewable energy. In J. W. Rowley QC, D. Bishop \& G. Kaiser (Eds.), The Guide to Energy Arbitrations (3rd ed.). London: Law Business Research. Retrieved from https://globalarbitrationreview.com/chapter/1178844/arbitrationsinvolving-renewable-energy 


\section{ENTREPRENEURSHIP AND SUSTAINABILITY ISSUES}

ISSN 2345-0282 (online) http://jssidoi.org/jesi/

2020 Volume 8 Number 2 (December)

http://doi.org/10.9770/jesi.2020.8.2(71)

Make your research more visible, join the Twitter account of ENTREPRENEURSHIP AND SUSTAINABILITY ISSUES: @Entrepr69728810

Lavranos, N. (2016, December 29). The German Constitutional Court judgment in the Vattenfall case: Lessons for the ECT Vattenfall Arbitral Tribunal [Blog post]. Kluwer Arbitration Blog. Retrieved from http://arbitrationblog.kluwerarbitration.com/2016/12/29/germanconstitutional-court-judgment-vattenfall-case-lessons-ect-vattenfall-arbitral-tribunal/

LB et al. v. the Republic of Lithuania, represented by the Ministry of the Economy, Lithuanian Supreme Administrative Court 12 June 2017 , Case No. eA-872-556/2017.

Masdar Solar Masdar Solar \& Wind v. Kingdom of Spain, ICSID Case No. ARB/14/1, Award, 16 May 2018.

Mikelënas, V. (2003). Lietuvos Respublikos Civilinio kodekso komentaras. Šeštoji knyga. Prievoliu teisè (I) [Commentary of the Lithuanian Civil Code. Sixth Book. Law of Obligations (I)]. Vilnius: Justitia.

Mizaras, V. (2007). Lietuvos deliktų teisés raidos aktualijos ir tendencijos [Issues and Tendencies of Development of Lithuanian Tort Law]. In Šiuolaikinés civilinès teisés raidos tendencijos ir perspektyvos: moksliniu straipsniu rinkinys [Trends and Perspectives in the Development of Contemporary Civil Law] (pp. 51-75). Vilnius: Justitia.

Nikièma, S. H. (2012). Best practices indirect expropriation. Winnipeg: The International Institute for Sustainable Development. Retrieved from https://www.iisd.org/sites/default/files/publications/best_practice_indirect_expropriation.pdf

Occidental Petroleum Corporation and Occidental Exploration and Production Company v. The Republic of Ecuador, ICSID Case No. ARB/06/11, Award, 12 Oct. 2005.

OECD. (2004). "Indirect expropriation" and the "right to regulate" in international investment law. OECD Working Papers on International Investment, 2004/04. OECD Publishing. http://dx.doi.org/10.1787/780155872321

Oliphant, K. (Ed.). (2016). The liability of public authorities in comparative perspective. Cambridge, Antwerp, Portland: Intersentia.

Parkerings-Compagniet AS v. Republic of Lithuania, ICSID Case No. ARB/05/8, Award, 11 Sep. 2007.

Potestà, M. (2013). Legitimate expectations in investment treaty law: Understanding the roots and the limits of a controversial concept. ICSID Review: Foreign Investment Law Journal, 28(1), 88-122. https://doi.org/10.2139/SSRN.2102771

Selelionytè-Drukteinienè, S. (2008). Valstybès deliktinès atsakomybès raidos tendencijos: daktaro disertacija [Developing trends of tort liability of the State: doctoral dissertation] (Mykolas Romeris University, Lithuania). Retrieved from https://aleph.library.lt/F?func=find-

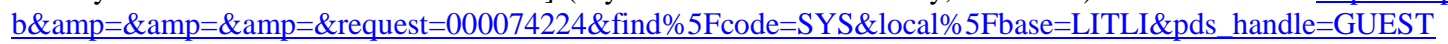

Saluka Investments v. Czech Republic, UNCITRAL, Partial Award, 17 Mar. 2006 (Perm. Ct. Arb.).

Suez, Sociedad General de Aguas de Barcelona S.A., and InterAgua v. The Argentine Republic, ICSID Case No. ARB/03/17, 30 July 2010.

Tecmed, S.A. v. United Mexican States, ICSID Case No. ARB(AF)/00/2, Award, 29 May 2003.

Total SA v. The Argentine Republic, ICSID Case No. ARB/04/1, 27 Dec. 2010.

Toto Costruzioni Generali S.p.A. v. The Republic of Lebanon, ICSID Case No. ARB/07/12, Award, 7 June 2012.

UAB Sunrita v. the Republic of Lithuania, Lithuanian Supreme Administrative Court 24 Nov. 2015, Case No. A-1314-552/2015.

UAB Baltlanta v. the Republic of Lithuania represented by the Ministry of Agriculture of the Republic of Lithuania, Lithuanian Supreme Administrative Court 30 Nov. 2015, Case No. A-1642-492/2015.

United Nations Conference on Trade and Development. (2012). Fair and equitable treatment: UNCTAD series on issues in international investment agreements II. New York: United Nations. Retrieved from https://unctad.org/en/Docs/unctaddiaeia2011d5_en.pdf

UV v. Lithuania, represented by the Ministry of Economy, Lithuanian Supreme Administrative Court 8 May 2017, Case No. eA-990$502 / 2017$. 


\section{ENTREPRENEURSHIP AND SUSTAINABILITY ISSUES}

ISSN 2345-0282 (online) http://jssidoi.org/jesi/

2020 Volume 8 Number 2 (December)

http://doi.org/10.9770/jesi.2020.8.2(71)

Make your research more visible, join the Twitter account of ENTREPRENEURSHIP AND SUSTAINABILITY ISSUES: @Entrepr69728810

Vattenfall AB and others v. Federal Republic of Germany, ICSID Case No. ARB/12/12.

Zielinski, L. Y. (2017, January 10). "Legitimate expectations" in the Vattenfall case: At the heart of the debate over ISDS [Blog post]. Kluwer Arbitration Blog. Retrieved from http://arbitrationblog.kluwerarbitration.com/2017/01/10/legitimate-expectations-in-the-vattenfall-case-at$\underline{\text { the-heart-of-the-debate-over-isds/?doing_wp_cron=1598446075.1607110500335693359375 }}$

Solveiga PALEVICIENE holds a PhD in law and is currently a professor at the Institute of Private Law at the Law School of Mykolas Romeris University, Lithuania. Her research interests include investment law, international arbitration and litigation, comparative contract and tort law.

Simona DRUKTEINIENE holds a PhD in law and is currently a professor at the Institute of Private Law at the Law School of Mykolas Romeris University, Lithuania. Her research interests include comparative tort law, state liability issues, national and international litigation.

ORCID ID: https://orcid.org/0000-0002-8426-3320

Copyright (C) 2020 by author(s) and VsI Entrepreneurship and Sustainability Center This work is licensed under the Creative Commons Attribution International License (CC BY). http://creativecommons.org/licenses/by/4.0/

c) (7) Open Access 